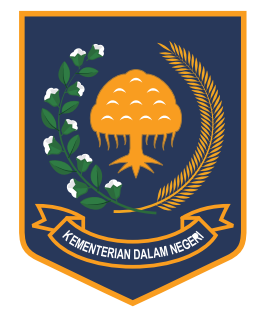

Jurnal Bina Praja 9 (1) (2017): 137-148

Jurnal Bina Praja

e-ISSN: 2503-3360 | p-ISSN: 2085-4323

Accreditation Number

735/AU2/P2MI-LIPI/04/2016

http://jurnal.kemendagri.go.id/index.php/jbp/index

\title{
THE IMPLEMENTATION OF INTEGRATED ADMINISTRATION SERVICES (PATEN) IN SIAK REgENCY, RIAU
}

\author{
Kemal * \\ Institute of Public Administration (IPDN) Riau \\ Ministry of Home Affairs \\ Banjar XII, Ujung Tanjung, Rokan Hilir Regency
}

Received: 8 March 2017; Accepted: 8 May 2017; Published online: 31 May 2017

DOI: $10.21787 /$ ibp.09.2017.137-148

\begin{abstract}
This research is about the Implementation of District Integrated Administration Service (PATEN) in bringing closer and improving services to the community in Siak Regency, Riau Province. Law Number 23 of 2014 on Regional Government states that District Heads must implement two authorities, namely Attributive authority, and Delegated authority. The District head as, a regional apparatus, is no longer the head of a region that must obtain a delegation of some of the authority of the Regent/Mayor as stipulated by Regent/Mayor regulation. Not all Regents/Mayors delegate part of the authority to District Heads so that the implementation of service is centered in Regency/City. This research uses a descriptive qualitative method, and data collection technique is in the form of the interview, observation, and documentation. The results revealed that (1) PATEN in Siak District can bring closer and improve service to the community free of charge; (2) There is a strong commitment from the Siak Regent in the delegation of some of the licensing authority to the District Heads. For example, the presence of service space in the district with service counters, PATEN officers, the incentives of PATENT officers, and the direct supervision from the Regent. (3) Positive responses from the community, such as better service, free, and close to the service recipient community.
\end{abstract}

Keywords: Authority Delegation, Integrated Administration, Service

\section{INTRODUCTION}

Since the New Order until the Reform Era, the amendment of the Law on Regional Government has entered the third round. The first round is Act Number 22 of 2001, Law Number 32 of 2004, and currently Act III of Law Number 23 of 2014. The amendment of Law regulating the Local Government at the same time changes the position of sub-district headed by District Heads, if Law Number 5 of 1974 in the New Order era claimed the status of District Heads as the central tool in the region in order to carry out the task of deconcentration, with the term of District Heads as the sole ruler of the territory. Then, there is a fundamental change in the law after that, which is Law Number 22 of 1999 which was then replaced by Law Number 32 of 2004 in which the districts headed by District Heads are no longer the central government device, but instead as the district/city regional device.

As explained in Article 120 Paragraph 2 of Law Number 32 of 2004 which states that Regency/ Municipality Regional Device consists of Regional Secretariat, Secretariat of DPRD, Regional Office, Regional Technical Institution, District, and SubDistrict. Then, at the end of SBY's leadership (Susilo Bambang Yudoyono) in 2014, the Law on Regional Government changed again with the birth of Law Number 23 of 2014. Then, along with the political dynamics of the country, further regulation on Regional Government is separated by regulation of regional head election and legislative election, then created Law Number 9 of 2015 Concerning the Second Amendment to Law Number 23 of 2014 has no change.

In principle, Law Number 23 of 2014 specifies the districts as compared to Law Number 32 of

\footnotetext{
* Corresponding Author

Phone : +62 82173941902

Email : revikemal@gmail.com
} 
2004. Law Number 23 of 2014 regulates in detail the formation of districts, the requirements of the formation of districts, reviving the classification of districts (such as in the Era of Law Number 5 of 1974) The delegation of some of the Regent's authority to the district heads, the duty of the district heads, the requirements to be appointed as a district head, and sub-districts financing charged to the regional budget of regency/city.

However, the three Laws on Regional Government above have the same principal in the case of the delegation of some of the authority of the Regent/Mayor to the District Head, although the District Head is carrying out two authorities, namely delegated authority and attributive authority. Delegated authority is the authority because there is a transfer from the Regent/Mayor. While attributive authority is an authority regulated by a higher regulation, as affirmed in Article 126 paragraph 3 of Law Number 32 of 2004 stated that, in addition to carrying out the task of devolving some of the authority of Regent/Mayor, the District Head also performs the general task of the government. However, since the Head of District is the Regional Device Work Unit (SKPD), who is appointed and dismissed by the Regent/Mayor, without any delegation of some authority of the Regent/Mayor to the District Head determined by the Regent/Mayor Regulation, the District Head does not necessarily execute the attributive authority.

One of the considerations of regional autonomy in districts/municipal governments emphasized not on the provincial government is to bring services closer to the community served (close to customers). Thus, it is hoped that district/city governments can more easily understand the growing empirical conditions in the community related to service needs.

Another opinion of regional autonomy suggests that the essence of decentralization is 'internalizing cost and benefit' for people and how to bring government closer to its people (Simanjuntak, 2015). With it, a service will be faster and the government will easily receive input from the community as a feedback from the quality of services provided. The emphasis of regional autonomy on the regency/city government indicates that all government authorities in the regency/ municipality are in the hands of the Regent/Mayor as a public official elected by the people. In this case, the Regent/Mayor may delegate some authority to the Agency, Board, Office, Technical Implementation Unit of the Region, District and Sub-District. With the delegation of some of the Regent/Mayor's authority to the Head of District, the Regent has a lot of time, mind, and energy to concentrate on formulating regional strategic policies by improving controlling functions.
The Government's leading unit is the district and sub-district closest to the community and better understand the problems and needs of the community. But in fact, there are still many Regents/Mayors who do not want to delegate some authority to the District Head (Wasistiono, Nurdin, \& Fahrurozi, 2009, p. 35).

Some studies on district services have not been specifically addressed on PATEN. However, some studies only discuss the optimization of services conducted by the district. Several studies on district services are conducted by Ilham \& Kemal (2015), J. (2009), Gunawan (2014), Nadeak (2014), and Halik (2014).

The results of Kemal's research (2015) conducted in Kampar Regency and the results of Ilham \& Kemal (2015) research in Kecamatan Bagan Sinembah Rokan Hilir Regency, Riau Province showed that there is no delegation of some of the authority of the Regent to the District Head. The District head is only a recommendation maker to the Regent, there are no services completed in the district. Thus, the services needed by the community are difficult, costly, time-consuming, and there is no certainty of service completion time.

Meanwhile, J. (2009) study concluded that the quality of district public services after the change of position and function of district head as regional apparatus is not yet optimal. Nevertheless, this research does not explain how the implementation of the delegation of some of the authority of the Regent to the District Head, but without the transfer of some of the authority of the Regent to the District Head, it is assured that public services will accumulate in the hands of the Regent and Regency Office/Agency.

This is reinforced by a research by Gunawan (2014) which concluded that there has been no devolution of some of the authority of the Mayor and Regent to the District Head. In addition, the district institutions and organizations have not been referring to Government Regulation Number 19 of 2008 on Districts. This research does not describe the affairs held by the district without any devolvement of some of the authority of the Regent/ Mayor to the District Head.

With regards to One Stop Integrated Services, the research conducted by Halik (2014) emphasized the perspectives of key performance indicators by formulating the formulation of several indicators to measure the quality of service but does not assess the implementation of integrated services in certain scopes, such as district.

The difference of this research with previous research is that this research not only examines the delegation of some of the authority of the Regent to the District Head, but in detail examines the Regent's policies that support the implementation of PATEN, 
supporting facilities, how the commitment and supervision of the Regent, and its output in the form of service improvement and closer service to the community. In contrast to the previous research which focused only on the quality of services conducted by the district and the types of services conducted that only follow the authority of the Regent.

The Central Government has already established Legislation in increasing the role and position of the District as the front line of government, as the closest unit to the community. Laws and Regulations that should be a reference for the Governor in exercising control over Regent/ Mayor policies on districts, and guidelines for Regent/Mayor in improving public services in the District, are; 1) Law Number 32 of 2004, amended by Law Number 23 of 2014 on Regional Government; 2) Law Number 30 of 2014 on Government Administration; 3) Government Regulation Number 19 of 2008 on Districts as the Regulation of the Implementation of Law Number 32 of 2004; 4) Minister of Home Affairs Regulation Number 4 of 2010 on District Integrated Administration Service Guidelines covering two scopes of services, namely licensing and non-licensing.

However, several previous research results indicated that not all Regent/Mayor have the commitment to delegate some of their authorities to the District Head. The existence of the gap between the provisions of the Regulations established with the commitment of Regents/Mayors, Governors as coaches of regency/city government has not been implemented thoroughly.

This study aims to reveal and describe the implementation of the Siak Regent policy on PATEN in approaching the service to the community, the implementation of delegation as the front-line unit of government service, as well as the responses of the recipient community to the implementation of PATEN.

\section{METHOD}

The research method used is descriptive qualitative research method with data collection techniques through observation, in-depth interviews, and documentation. The method is to gain a deep understanding in revealing and describing the phenomenon on the implementation of PATEN. As Strauss \& Corbin (1990, p. 19) puts it, "qualitative methods can be used to uncover and understand the issue of the phenomenon that is difficult to convey with quantitative methods".

Prior to the research, the researcher have formulated the research steps as proposed by Miles and Huberman (1984) in Creswell (2002, p. 139) which suggests that researchers should consider four suggested measures, the background (where the study will take place), the actor (the person to be observed or interviewed), events (what will be observed or interviewed), and processes (nature of events actors do in the background).

The technique of Data collection is conducted by observation, in-depth unstructured interviews, and document review. It is done by referring to Creswell's opinion (1994, p. 149) "data collection procedures in qualitative research involve four basic types: observations, interviews, documents, and visual images". The informants of this research are: Regent/Vice Regent, Regional Secretary, Government Assistant, Head of Administration of General Government, Head of Agency/Office related to the authority delegated to District Head, District/ Licensing Officer, and community.

In the determination of District Heads as the informants of the 14 (fourteen) districts in Siak Regency, due to limited time and cost of research, the researcher took samples in five sub-districts of 14 districts in Siak Regency, District sampling is done by purposive sampling, which means the collection of data with certain considerations (Sugiyono, 2005). The researcher uses some considerations in the determination of districts as the mobilization of districts is low and high, the distance of districts is far and closest to the regency capital, the district is a difficult category. So, it can be concluded that the five districts are Koto Gasib District, Sungai Apit District, Kandis District, which is the farthest distance, Minas District, and Tualang District.

Meanwhile, the determination of informants from the service recipients in the districts determined as the location of the data source is determined by non-probability sampling. Nonprobability sampling is a sample taken from anyone who happens to be there (Nasution, 2008, p. 98). For data validity, this study uses credibility through triangulation as stated by Creswell (1994, p. 196), Bungin (2004, p. 330), and Sugiyono (2005, p. 83). While triangulation used by cross-checking against some data source and documentation and from the result of observation. The location of this research is 14 districts in Siak Regency of Riau Province. From the 14 districts, five districts are selected based on districts that have the farthest distance and closest to the capital, the relatively low districts, and the most difficult to reach district.

\section{RESULTS AND DISCUSSION}

\section{A. The Implementation of PATEN in Bringing Closer and Improving Services to the Community}

Siak Regency is better known as the icon of Siak Kingdom Palace located in the heart of Siak Regency Capital in Siak Indrapura and is located 
Table 1.

The Number of Village/Urban-villages, Neighborhood (RT), Hamlet (RW) per District

\begin{tabular}{clccc} 
No. & \multicolumn{1}{c}{ Sub-District } & Village/Urban-Village & RK/RW & RT \\
1 & Minas & 5 & 41 & 124 \\
\hline 2 & Kandis & 11 & 110 & 297 \\
\hline 3 & Siak & 8 & 29 & 87 \\
\hline 4 & Sungai Apit & 15 & 73 & 170 \\
\hline 5 & Sungai Mandau & 9 & 29 & 59 \\
\hline 6 & Kerinci Kanan & 12 & 68 & 193 \\
\hline 7 & Lubuk Dalam & 7 & 27 & 343 \\
\hline 8 & Tualang & 9 & 563 & 139 \\
\hline 9 & Koto Gasib & 11 & 48 & 203 \\
\hline 10 & Dayun & 11 & 66 & 157 \\
\hline 11 & Bunga Raya & 10 & 61 & 68 \\
\hline 13 & Mempura & 8 & 29 & 91 \\
\hline
\end{tabular}

Source: Siak in Numbers, 2015

beside Siak River. Siak River becomes a means of transportation that is always passed by Ferry boat of Pekanbaru-Malacca, Johor, and Singapore routes. Prior to the construction of several bridges in Siak Regency after the extension, the river is a reliable means of transportation for people connecting between villages, between districts to the capital of Bengkalis Regency and to the capital of Riau Province in Pekanbaru.

Before pemekaran became New Autonomous Region (DOB) in 1999, Siak District was previously included in the administrative area of Bengkalis Regency. In which the administrative region consists only of three districts namely District River Apit, Siak District and District Minas. Then, based on Law of the Republic of Indonesia Number 53 of 1999, Siak Regency was formed along with the establishment of several new autonomous regions in Riau Province.

During the study (November 2016), Siak District continued to expand the administrative area of government and is now 14 districts, nine subdistricts, 122 villages, with a population of 473,387 people.

In Siak Regency, the formation of SKPD is still referring to Government Regulation Number 41 of 2007 on Regional Device Organizations (when the research in the process of drafting the OPD refers to Government Regulation Number 18 of 2016 on Organization of Regional Devices).

Siak District Government holds 25 compulsory functions, and 8 (eight) selected affairs. SKPD of Siak Regency that is still valid at the time of research (2016) consists of Regional Secretariat, DPRD Secretariat, Inspectorate, 8 Agencies, 14 Boards, 2 Offices, 1 Regional Hospital, 14 Districts, and 9 Sub-districts. While the number of villages in Siak Regency as many as 122 villages with a population of 473,387 inhabitants (Source: Regent Expose Document, 2014).

\section{B. District in Siak Regency}

There are 14 districts, nine sub-districts, and 122 villages. For more details, described in Table 1.

of the 14 sub-districts, from Table 1, the researcher determines the districts that become the research object based on the methodology used. The researcher chose the districts classified as low and high, the distance of districts that are the farthest and the closest to the regency capital, and districts with 
Table 2 .

Districts Based on Width, Population Number, and Density per km

\begin{tabular}{|c|c|c|c|c|}
\hline No. & District & $\begin{array}{l}\text { Width } \\
(\mathbf{k m})\end{array}$ & Population & $\begin{array}{l}\text { Density } \\
\text { per km2 }\end{array}$ \\
\hline 1 & Minas & 346.35 & 31,939 & 92.22 \\
\hline 2 & Kandis & $1,493.65$ & 82,349 & 5.13 \\
\hline 3 & Siak & 894.17 & 27,548 & 30.81 \\
\hline 4 & Sungai Apit & $1,346.33$ & 30,929 & 22.97 \\
\hline 5 & Sungai Mandau & 1,705 & 7,445 & 4.37 \\
\hline 6 & Kerinci Kanan & 128.66 & 25,827 & 200.74 \\
\hline 7 & Lubuk Dalam & 155.09 & 20,800 & 134.12 \\
\hline 8 & Tualang & 343.6 & 126,442 & 367.99 \\
\hline 9 & Koto Gasib & 704.7 & 23,488 & 33.33 \\
\hline 10 & Dayun & 232.24 & 32,591 & 140.33 \\
\hline 11 & Bunga Raya & 151 & 26,192 & 173.46 \\
\hline 12 & Mempura & 437.45 & 16,323 & 37.31 \\
\hline 13 & Sabah Auh & 73.38 & 12,789 & 174.28 \\
\hline \multirow[t]{2}{*}{14} & Pusako & 544.47 & 6,668 & 12.25 \\
\hline & Jumlah & $8,556.09$ & 471,330 & 55.09 \\
\hline
\end{tabular}

Source: Siak in Numbers, 2015

the difficult category. First, the researcher chose the district with the largest number of villages/urbanvillages. The district is Sungai Apit District which has 15 villages/urban-villages. In addition, Kandis District has the highest number of RK/RW and RT, 190 RW, and 297 RT.

The next district is Minas, which has the fewest number of villages. In addition, Minas has similarities with Kandis as a lane for crossing Pekanbaru-Dumai as well as the Riau-North Sumatra Road.

When viewed from the population, the district with the largest population is Tualang District with a population of 126,442 people and the population density of 367,99 people/km. Districts with the most widespread areas are Kandis and Apit River, where Kandis is a subdistrict traversed by transSumatra road, while the Apit River is the oldest district. The most populated district and the largest population density per $\mathrm{km}$ are Tualang District. In addition to the broad aspect of the area, the population, the density of the population that needs to be considered in an effort to bring public services closer to the community is the distance of the district capital to the capital of Siak Regency. The distance is from the District Capital to the Siak Regency Capital.

The District furthest from the capital of Siak Regency is Kandis District, with a distance of $87 \mathrm{~km}$. But Kandis access to Siak Sri Indrapura (the capital) is quite smooth. Several districts in Siak Regency prior to area extension can only be passed through river transportation such as Sungai Mandau and Pusako districts. It is just recently in 2016 that it can be passed by road; similarly, to all the Districts in the Regency.

The problem that often occurs in the community who need service to the regency government office is the unavailability of public transport. Some people do not own private vehicles. Such as Teluk Lanus Village, Sungai District, which distance is 117 $\mathrm{km}$ and can only be passed by river transportation. In addition, the average distance of the village/ urban-village to the district capital is a maximum of $15 \mathrm{~km}$, except for two districts, namely Koto Gasib and Sungai Apit.

The following illustrated the cost borne by the people of Teluk Lanus Village when going directly 
Table 3.

Distance of District to Siak Regency Capital

\begin{tabular}{|c|c|c|}
\hline Siak Regency Capital & District Capital & Distance (km) \\
\hline \multirow[t]{14}{*}{ Siak Sri Indrapura } & 1. Siak & 0 \\
\hline & 2. Mempura & 4 \\
\hline & 3. Dayun & 17 \\
\hline & 4. Bunga Raya & 18 \\
\hline & 5. Pusako & 25 \\
\hline & 6. Pangkalan Pisang & 25 \\
\hline & 7. Lubuk Dalam & 32 \\
\hline & 8. Sabah Auh & 34 \\
\hline & 9. Sungai Apit & 37 \\
\hline & 10. Muara Kelantan & 38 \\
\hline & 11. Kerinci Kanan & 38 \\
\hline & 12. Perawang & 49 \\
\hline & 13. Minas & 66 \\
\hline & 14. Kandis & 87 \\
\hline
\end{tabular}

Source: Siak in Numbers, 2015

to the District and Siak Regency, more or less will cost IDR125,000, it includes the cost of pompong (traditional boat) to Buton/Sei Kayu Ara, Other cost is IDR50,000 for the cost of the Buton-Apit Motorcycle taxi, plus IDR90,000 for the ride on the Apit River ride to the Regency Capital. So that the total is IDR265,000.

The cost to the public is IDR265,000 for one way, which means that the return cost to the village is equal to the cost of leaving so that the total round trip reaches IDR530,000. That is the cost to the public for the administration of population administration. Not including the cost of meals and lodging costs when the administration matter is not completed in one day.

\section{Siak Regent Policies Towards PATEN Implementation}

\section{1) Formulate and Stipulate Regulation of Siak Regent}

The results of this study indicate that, prior to establishing several policies related to PATEN, the Siak District Head held discussions with the Head of SKPD, DPRD Members, including the District Head and urban-village heads on which authority is eligible to be delegated to the District Head. Once discussed, then formulated some Regulations of Siak Regent related to PATEN.

The Regent of Siak has set as many as five Regents Regulations to support the implementation of PATEN, among them the regulation of the Regent Regarding the Establishment of UPTD (Technical Implementation Unit) in each district, Regent Regulation on the Delegation of some Regent's authority to district Head, Regent Regulation on PATEN Manager's Duties in Siak Regency, which guides the District Head's work in the implementation of PATEN, establishes the Regent's Regulation on Service Standards and PATEN Licensing districts of Siak Regency, and the last is the Regent of Siak Regent Regarding the Incentives of PATEN Officers in the District. After stipulating the Regent's Regulation, then conducted dissemination, technical guidance for District Head and PATEN Officers.

2) Regent's Policy about District Operational Fund, Service Room, and Incentive of District 
Table 4.

District Operational Fund in Siak Regency

\begin{tabular}{|c|c|c|c|}
\hline \multirow{2}{*}{ No. } & \multirow{2}{*}{ District } & \multicolumn{2}{|c|}{ Yearly Budget (IDR) } \\
\hline & & 2015 & 2016 \\
\hline 1 & Minas & $3,477,877,040$ & $5,292,482,400$ \\
\hline 2 & Kandis & $1,576,169,140$ & $3,185,991,640$ \\
\hline 3 & Siak & $4,368,170,720$ & $4,636,607,260$ \\
\hline 4 & Sungai Apit & $3,923,178,864$ & $4,069,227,280$ \\
\hline 5 & Sungai Mandau & $3,370,758,270$ & $3,112,045,420$ \\
\hline 6 & Kerinci Kanan & $3,101,398,240$ & $2,411,354,040$ \\
\hline 7 & Lubuk Dalam & $2,680,355,250$ & $3,049,733,330$ \\
\hline 8 & Tualang & $2,903,390,700$ & $3,030,173,540$ \\
\hline 9 & Koto Gasib & $4,326,619,140$ & $4,606,478,380$ \\
\hline 10 & Dayun & $2,847,232,680$ & $2,901,552,520$ \\
\hline 11 & Bunga Raya & $3,201,700,620$ & $3,079,884,420$ \\
\hline 12 & Mempura & $3,016,380,371$ & $2,599,170,520$ \\
\hline 13 & Sabah Auh & $4,386,911,430$ & $3,609,009,495$ \\
\hline 14 & Pusako & $4,352,098,940$ & $3,040,686,560$ \\
\hline
\end{tabular}

Source: SKPD Budget Document of Siak Regency Government of 2015, 2016, Regional Planning Agency (Bappeda) of Siak Regency

\section{PATEN Officer}

To support the implementation of PATEN, Siak Regent has a strong commitment, which is shown in addition to allocating District Head's operational funds that are relatively big, and also provides funds to arrange the District Head office space into a service room with service counters similar to the Bank, and incentives for District PATEN officials.

The District Operational Fund in Siak Regency for Budget Year 2016 is around IDR2,5 - IDR5,2 billion. For officers of a counter in PATEN service room, the policy of Siak Regent gives incentive for temporary staffs or civil servants (State Civil Apparatus) of IDR1,300,000/month, excluding monthly salary or honorarium for temporary staffs.

Some facilities and infrastructures are built to support the implementation of PATEN, such as counter/registration table, processing place, document submission, data and information management place, complaint handling, picket place, waiting room, and other supporting equipment.

Each district has an innovation to design the PATEN service space. In some offices, there are children's playrooms (in Koto Gasib District office), there are counters like at Bank, equipped with various attributes of Public Service requirements as Regulated in Law Number 25 of 2009 on Public Service. On the other hand, there are also service requirements, SOP (standard operational procedures), notices, and suggestion boxes to determine the level of community satisfaction with the services provided (in Tualang District).

\section{3) Direct Supervision of Siak Regent}

In the implementation of PATEN, Siak Regent Regulation Number 5 of 2012 on Duties Implementing the Integrated Administrative Service Sub-District (PATEN) in Siak, affirmed: "it is not justified for any collection except restitution fees as regulated by local regulations". If there is a District Head or District Device that collects fees or complicate services to the public, the affected communities can directly report directly through the Regent's mobile phone number listed in each district. Regent will immediately call the concerned District Head if there is a report. As one of the 
District Heads explained. "If the Regent calls us to the Regent's office and then he holds the Mobile Phone, then we are already frightened and anxious. There is certainly a report on our negligence, "he said.

Direct supervision from Siak Regent to Head of District and Head of SKPD is very effective in combating corruption or complicating service to the public.

\section{The Implementation of the Delegation of the Regent's Authority to the District Heads}

To support the implementation of PATEN, the Siak Regent not only stipulates the Siak Regent's Regulation on the Delegation of some of the Regent's authorities to the District Heads but also sets out some policies established by the Regent through the Regulation of Siak Regent, as follows:

\section{1) Siak Regent's Regulation on Establishment of UPTD in the District}

To support the duties of the District Head in the implementation of PATEN, as related to the technical service of the Agency/Board/Office, the Regent of Siak stipulates 13 Regent Regulations on the Establishment of 13 UPTD as an extension of Agency/Board in each district. Considering the level of community mobilization, the potential of each district is not the same as budget efficiency considerations, the establishment of one UPTDs includes two adjacent districts.

\section{2) Siak Regent's Regulation Number 42 of 2011 on the Delegation of some of the Regent's Authority to the District's Head}

It is with reference to Government Regulation Number 19 of 2008 on Districts and Minister of Home Affairs Regulation Number 4 of 2010 on District Integrated Administration Service Guidelines. Based on the researcher's analysis of Siak Regent Regulation Number 42 of 2011, then the aspect of authority is delegated to the District Head, as described in Table 5.

As in Table 5, the Siak Regent delegates as many as 218 types of authorities to the District Heads. In addition to performing delegated tasks delegated by the Regent, District Heads also perform attributive tasks, which are tasks that are governed directly by the Law and Government Regulation, namely the general tasks of governing (Article 15 Paragraph 1 of Government Regulation Number 19 of 2008) which consists of seven Types of coordination. In the Siak Regent Regulation on the Delegation of the some Regents's Authorities to the District Heads, detailed 74 types of service permits delegated to the District Heads. The results of the research show that from 74 types of licensing services delegated to
Table 5.

Aspects of Delegation of Authority of Siak Regent to District Heads

\begin{tabular}{clc} 
No. & Authority Aspects & Total \\
1 & Licensing & 74 \\
\hline 2 & Recommendation & 25 \\
\hline 3 & Coordination & 10 \\
\hline 4 & Development & 16 \\
\hline 5 & Supervision & 29 \\
\hline 7 & Facilitation & 36 \\
\hline 8 & Stipulation & 5 \\
\hline & $\begin{array}{l}\text { Other Duties } \\
\text { Implementation }\end{array}$
\end{tabular}

District Heads, the types of services required by the community are as much as 13 types of services, as described in Table 6.

In the implementation of PATEN, there are only two types of licenses completed in the district, namely SIUP and IMB with a building area of $100 \mathrm{~m} 2$, while 72 other licensing are only a recommendation in terms of services that are not completed in the district (one stop service).

The results of the research show that the 13 types of services that many people require are the services of population administration, such as family card and E-KTP, but District Heads only give recommendation while for the electronic data recording, the people must come to the Department of Population and Civil Registry in Siak Regency. Because the recording of E-KTP cannot be done in the Districts because the E-KTP computer devices are damaged and blank forms for ID card are not available (if any, they are in a limited amount).

\section{3) Siak Regent's Regulation Number 5 of 2012 on Duties of PATEN Managers \\ Siak Regent's Regulation Number 5 of 2012} on Description of Duties of PATEN Implementers in Siak Regency, is a guideline for District Head's work in the implementation of PATEN. The regulation also regulates the establishment of PATEN organizer officials, also describes the description of their respective duties, as well as PATEN facilities and infrastructure, charged To Siak Regency Budget.

The PATEN Operator Officer in Article 2 of the Proposal is the District Head, the District Secretary, 
Table 6.

Types of Licensing Services Needed by the Community

\begin{tabular}{|c|c|}
\hline Aspects & Licensing Types \\
\hline 1. Licensing & $\begin{array}{l}\text { - Installation of } \\
\text { billboards; } \\
\text { - } \text { Rooms and } \\
\text { nightclubs; } \\
\text { - Optical; } \\
\text { - } \text { Business Location } \\
\text { Permit; } \\
\text { - Nuisance Permit } \\
\text { (HO); } \\
\text { - Building Permit } \\
\text { (IMB); } \\
\text { - Business License } \\
\text { (SIUP). }\end{array}$ \\
\hline 2. Recommendation & $\begin{array}{l}\text { - } \text { Family Card } \\
\text { - } \text { ID Card } \\
\text { Recommendation; } \\
\text { - Certificate of } \\
\text { Inability; } \\
\text { - Relocating Letter; } \\
\text { - Proposal Service; } \\
\text { - } \text { Birth Certificate } \\
\text { - Recommendation } \\
\text { - Land Certificate } \\
\text { Recommendation }\end{array}$ \\
\hline Total & 13 service types. \\
\hline
\end{tabular}

and the Section Head. While PATEN technical implementers (article 8) include information officers, bankers/receivers, computer operators, cash handlers, and other officers as required.

The Regent of Siak's Regulations explains in detail the extent of the duties of each PATEN organizer official and technical officer.

Article 10 of Siak Regent's Regulation as described in the previous section also describes the facilities and infrastructure that support the implementation of PATEN, including counter/ registration table, file processing, payment place, document submission, data and information management, and complaint handling.

\section{4) Siak Regent Regulation Number 6 of 2012 on}

Standard Services Licensing and Non-Licensing

PATEN in the Sub-District of Scope in Siak

To support the implementation of the Siak Regent's two policies outlined in the previous section, the Siak Regent reiterated the regulation policy of Regent Number 6 of 2012 on Service Standards and PATEN Licensing at Districts in Siak Regency. The Regent's Regulation details the Components of Service Standards, Types of Licensing, and Non-Licensing as well as Guidance and PATEN service providers.

In Article 6 Paragraph 1 of Siak Regent Regulation Number 6 of 2012, described the components of licensing and non-licensing service standards of PATEN, among other types of services, the legal basis of service, service requirements; Procedures and mechanisms of service; Service charge; service process duration.

The above standard component of service complies with the provisions set forth in Article 21 of Law of the Republic of Indonesia Number 25 of 2009 on Public Service, although some other components such as executing competence, service guarantee, security guarantee, and performance evaluation are not included in the Regent's Regulation, the implementation of these components have been implemented in accordance with the conditions and the ability of existing apparatus resources.

Based on the result of research on the above components, it shows that each District put it in the PATEN room. Even the five districts that became the sample of the study added the component of the level of community satisfaction to the service provided by the districts.

\section{5) Regent's Policy on the Provision of Honorarium/Incentives of District PATEN Officers}

As stated in the Budgetary Implementation Document (DPA) of SKPD of Siak Regency 2015 and 2016, the District Government provides incentive funding for District Officials and PATEN Teams. Funds provided is IDR1,300,000 per month for PATEN Counter Officers, For Secretary of PATEN Team is IDR2,500,000 per month, while District Head as the Chairman as well as the person in charge of PATENT implementation is IDR3000,000 per month. In addition to the provision of incentives or honorarium, also given a special uniform for PATEN District Officers, thus giving the impression of service as in the bank.

\section{E. Response of PATEN Receiver Community}

With the policy of Siak Regent in the implementation of District Administration Service (PATEN), the service to the community becomes quicker, the cost of transportation (transport and accommodation costs) is less, does not take long, so the public gives satisfied response to the policy of Siak Regent.

\section{1) Free of Charge Service \\ of the 74 types of licensing services submitted by the Regent to the District Head, all services are conducted free of charge, except for the restitution regulated in the Regional Regulation of Siak Regency.}




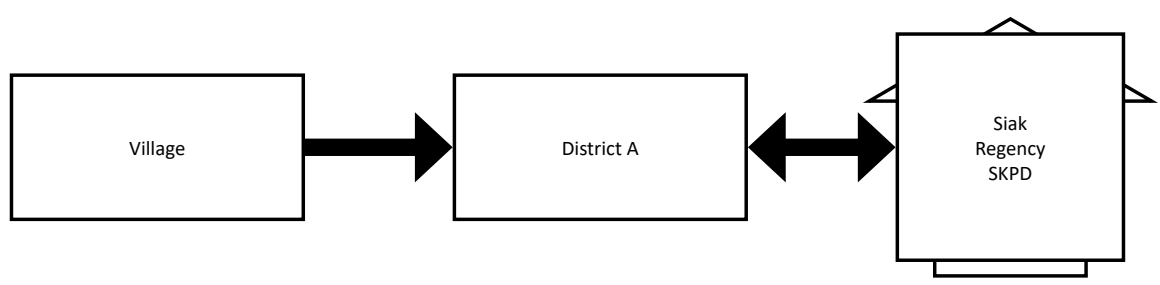

Figure 1. The Bureaucratic Chain of Service Prior to PATEN

\section{2) Service Bureaucracy Becomes Short}

As illustrated in the previous description of the illustration of the service chain to the community before the Siak Regent's policy on PATEN was established, with the geographical condition of Siak Regency that has many rivers and relatively distant and the unavailability of public transportation facilities in some Districts, for transport services to be relatively expensive as well take a relatively long time. As the previous illustrations, it should cost a lot. With the implementation of PATEN, the bureaucratic chain of service to the community becomes shorter, the cost of transportation is cheaper, and the certainty of the timing of the completion of service.

The bureaucratic chain of service to the community prior to the Siak Regent's policy on PATEN may be described as seen in Figure 1.

From Figure 1, the sea transport facility from Teluk Lanus Village with the direct route to Siak Sri Indrapura has a departure schedule 2 times a week (no daily schedule). For one departure, the public must stay 2-3 nights in the capital district. After the PATEN policy, the bureaucratic link of public service becomes short as shown in Figure 2.

With the relatively close distance between the Village of the Capital District, then the cost of transportation of people who need services will be cheaper with the PATEN.

\section{3) Communities Can Report Directly to Siak Regent}

Another satisfaction is that people can report via cellular phone or report directly to the Regent on charges or things that complicate community affairs by District Head or District Devices. The community can contact directly the regent's number, which is widely informed in the district office. Regent also will not hesitate to deal with District Heads related if there are reports from the community. So, with the supervisory model made by the Regent, it becomes effective in reducing the society complaints against local government services. Thus, the people feel satisfied, in addition to the policy of the Siak Regent in PATEN, and also the seriousness of the Regent in conducting supervision of the District Head and the District devices.

If there is a report from the community through the Regent's cellular phone, the Regent will immediately call the concerned person to confirm the complaint, if found guilty.

\section{Conclusion}

From the research results can be concluded that there is a real effort from Siak Regent in implementing PATEN, starting from the existence

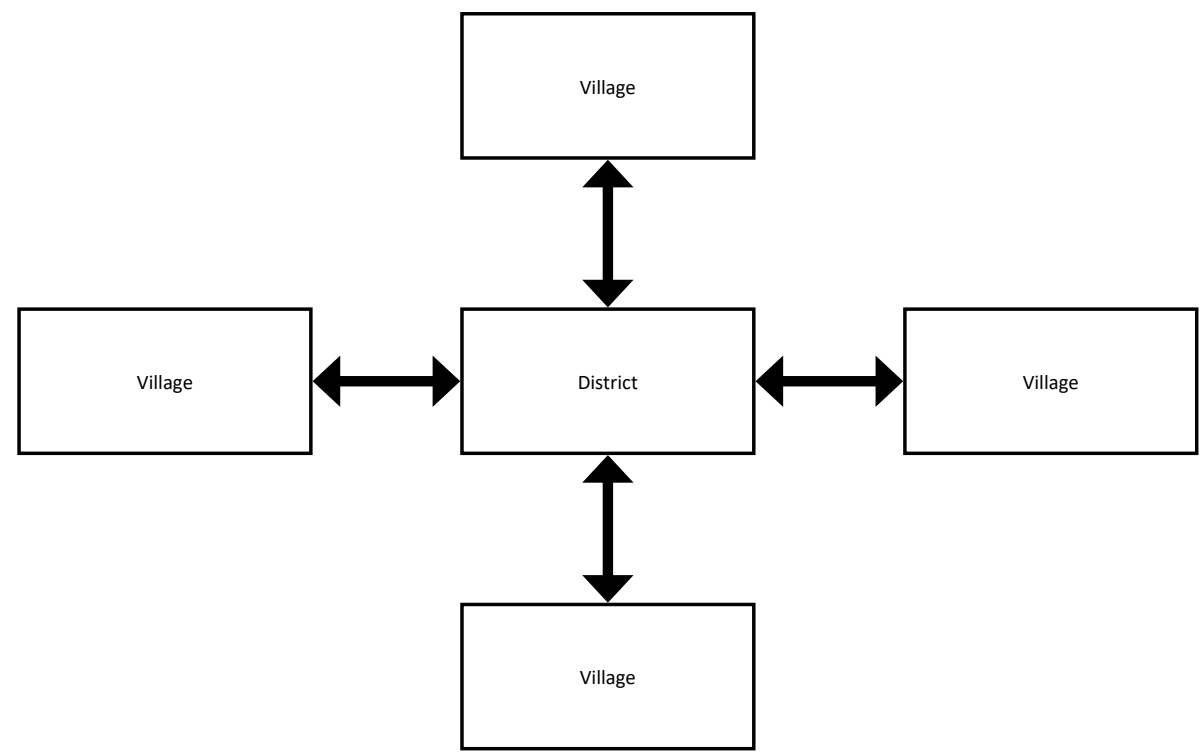

Figure 2. The Bureaucratic Chain of Community Service 
of political will of Siak Regent by stipulating various policies, namely the delegation of authority, setting up PATEN supporting policies, socialization of policies, resources, PATEN supporting facilities, and direct supervision from Siak Regent. In addition, there is also an implementation of the delegation of some of the authorities of the Regent to the District Head, the Regent gave 74 types of licensing services to the District Head. Of the 74 types of licensing delegated to the District Head, there are only 13 types of permits needed by the community. To support the Regent's policy on delegating authority to district heads, the Regent established several policies, namely the establishment of UPTDs in each district, the policy of establishing PATEN Team in each district, PATEN spatial allocation budget policies, and PATEN officer incentives.

The study also concluded that the implementation of PATEN receives a positive response from the community because it can bring the services closer and better to the community. Such as free service, shortening the service bureaucracy chain, does not take long, and the existence of Public complaints to the Regent directly.

\section{SUGGESTIONS}

1. To establish one-door coordination between the Head of District and Head of UPTD, the need of Siak Regent's Policy for the absence of Head of UPTD is signed by the District Head, and UPTD room is available at the PATEN service counter of the district, so that in the implementation of PATEN, the people no longer need to commute from the District Head's office to the UPTD office and then back to the District Head's office, thus extending the bureaucratic chain in the District;

2. Population administration services such as family cards, ID cards, and birth certificates are advised to the Head of Population and Civil Affairs of the matter discussed in a meeting with the Directorate General of Population and Civil Records of the Ministry of Home Affairs. And it is suggested to the Minister of Home Affairs that the matters related to e-KTP should be handed over to the local government so that it does not extend the polemic of national ID card, but strengthened by the Central Government supervision, in this case, the Director General of Population and Civil Records, to the local government;

3. To improve the performance of PATEN in Siak District to be accompanied by the construction of new District head's office in Siak Regency, considering the current District Head' office building is not feasible because it is an office built at the early extension of Siak Regency. The District Head's office should be the front line of government, gateway (front gate) of Siak Regency, and become one of the dimensions of achievement level of Siak Regency development.

\section{REFERENCES}

Bungin, B. (2004). Metodologi Penelitian Kualitatif. Jakarta: Raja Grafindo Persada.

Creswell, J. W. (2002). Research Design: Pendekatan Kualitatif, Kuantitatif, dan Mixed. Jakarta: Kik Press.

Government Regulation Number 18 of 2016 on Organization of Regional Devices, Pub. L. No. 18 (2016). Indonesia.

Government Regulation Number 19 of 2008 on Districts, Pub. L. No. 19 (2008). Indonesia.

Gunawan. (2014). Peran dan Fungsi Kecamatan dalam Penyelenggaraan Pemerintahan Daerah di Kota Semarang dan Kabupaten Semarang Provinsi Jawa Tengah. Jurnal Bina Praja, 6(4), 315-328. http://doi.org/10.21787/ jbp.06.2014.315-328

Halik, A. (2014). Kajian Pengembangan Kebijakan Pelayanan Terpadu Satu Pintu (PTSP) melalui Perspektif Indikator Kinerja Utama (IKU). Jurnal Bina Praja, 6(1), 1-18. http://doi. org/10.21787/jbp.06.2014.41-50

Ilham, M., \& Kemal. (2015). Pemberdayaan Kecamatan dalam Meningkatkan Pelayanan Kepada Masyarakat di Kecamatan Bagan Sinembah Kabupaten Rokan Hilir.

J., R. A. (2009). Kualitas Pelayanan Publik Kecamatan Setelah Perubahan Kedudukan dan Fungsi Camat sebagai Perangkat Daerah. Bisnis \& Birokrasi, Jurnal Ilmu Administrasi Dan Organisasi, 16(2), 87-95. http://doi. org/10.20476/jbb.v16i2.609

Kemal. (2015). Pemberdayaan Kecamatan dalam Meningkatkan Pelayanan Publik (Kasus Pada Pemerintah Kabupaten Kampar).

Law of the Republic of Indonesia Number 22 of 1999 on Regional Administration, Pub. L. No. 22 (1999). Indonesia.

Law of the Republic of Indonesia Number 23 of 2014 on Regional Administration, Pub. L. No. 23 (2014). Indonesia.

Law of the Republic of Indonesia Number 23 of 2014 on Regional Government, Pub. L. No. 23 (2014). Indonesia.

Law of the Republic of Indonesia Number 25 of 2009 on Public Service, Pub. L. No. 25 (2009). Indonesia.

Law of the Republic of Indonesia Number 30 of 2014 on Government Administration, Pub. L. No. 30 (2014). Indonesia.

Law of the Republic of Indonesia Number 32 of 2004 on Regional Administration, Pub. L. No. 32 (2004). Indonesia. 
Law of the Republic of Indonesia Number 53 of 1999 concerning the Formation of Pelalawan Regency, Rokan Hulu Regency, Rokan Hilir Regency, Siak Regency, Karimun Regency, Natuna Regency, Kuantan Singingi Regency and Batam City, Pub. L. No. 53 (1999). Indonesia.

Law of the Republic of Indonesia Number 5 of 1974 on the Principles of Governance in the Region, Pub. L. No. 5 (1974). Indonesia.

Law of the Republic of Indonesia Number 9 of 2015 Concerning the Second Amendment to Law Number 23 of 2014 on Regional Government, Pub. L. No. 9 (2015). Indonesia.

Minister of Home Affairs Regulation Number 4 of 2010 on District Integrated Administration Service Guidelines, Pub. L. No. 4 (2010). Indonesia.

Nadeak, H. (2014). Implementasi Peraturan Pemerintah Nomor 19 Tahun 2008 tentang Kecamatan. Jurnal Bina Praja, 6(3), 183-196. http://doi.org/10.21787/jbp.06.2014.183195

Nasution, S. (2008). Metode Research. Jakarta: Bumi Aksara.
Siak Regent Regulation Number 42 of 2011 About Delegation of Authority Some Regents to the Camat to Implement the Local Government Affairs, Pub. L. No. 42 (2011). Indonesia.

Siak Regent Regulation Number 5 of 2012 on Duties Implementing the Integrated Administrative Service Sub-District (PATEN) in Siak, Pub. L. No. 5 (2012). Indonesia.

Siak Regent Regulation Number 6 of 2012 on Standard Services Licensing and Non-Licensing PATEN in the Sub-District of Scope in Siak, Pub. L. No. 6 (2012). Indonesia.

Simanjuntak, K. M. (2015). Implementasi Kebijakan Desentralisasi Pemerintahan di Indonesia. Jurnal Bina Praja, 7(2), 111-130. http://doi. org/10.21787/jbp.07.2015.111-130

Strauss, A. L., \& Corbin, J. M. (1990). Basics of Qualitative Research: Grounded Theory Procedures and Techniques. Sage Publications.

Sugiyono. (2005). Memahami Penelitian Kualitatif. Bandung: Alfabeta.

Wasistiono, S., Nurdin, I., \& Fahrurozi, M. (2009). Perkembangan Organisasi Kecamatan dari Masa ke Masa. Bandung: Fokusmedia. 